Historic, Archive Document

Do not assume content reflects current scientific knowledge, policies, or practices. 

$$
1084 \operatorname{pin} \pi 925
$$

Ag 84Pro cop. 2
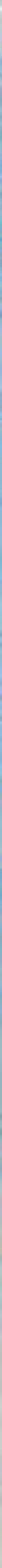

\section{duck virus enteritis an old world disease $\ldots$... in the new world}




\section{DUCK VIRUS ENTERITIS an old world disease . . . in the new world}

Duck virus enteritis, or Dutch duck plague, is a contagious disease of waterfowl that causes internal bleeding and severe diarrhea and kills many infected birds. Domestic and wild ducks, geese, and swans are susceptible.

Before 1967, this foreign disease was unknown in the United States. That year it suddenly appeared in the heart of the commercial duck industry on Long Island. Prompt enforcement of control measures confined the outbreak to New York State.

Duck virus enteritis does not affect humans.

\section{WHERE IT OCCURS}

Duck virus enteritis is established in the Netherlands. Occasional outbreaks occur in a small area, but the disease is not widespread.

It was described as a distinct disease in 1949. Dutch scientists then learned that signs of duck virus enteritis were observed in ducks in 1923, 1932, and 1942. However, the earlier outbreaks had been mistakenly diagnosed as fowl plague.

Duck virus enteritis has also been reported in Belgium, India, and China. The disease has not become widespread, and it has not invaded neighboring countries.

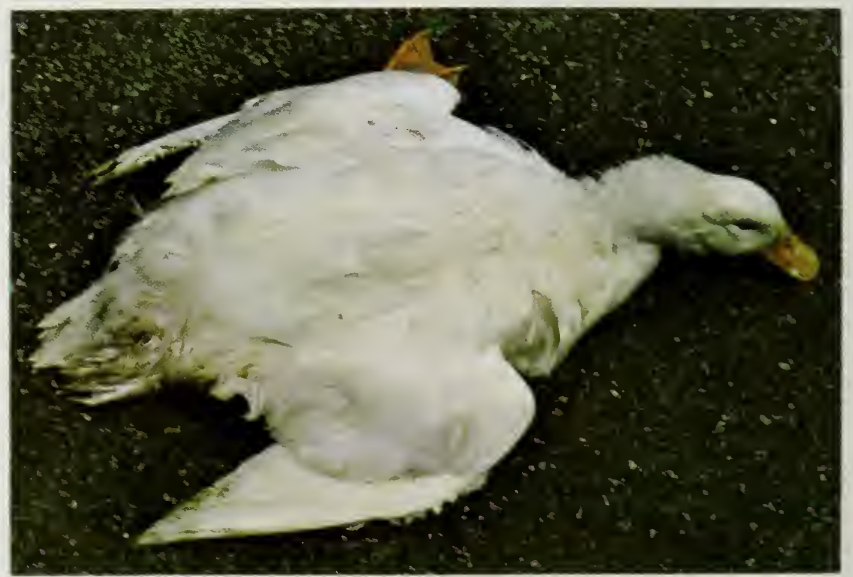

Duck infected with duck virus enteritis is unable to walk normally. It creeps and stretches its wings listlessly. 
Most U.S. outbreaks have occurred in commercial duck flocks on Long Island. The disease has also killed free-flying waterfowl on Long Island and a small number of migratory birds raised in captivity in New York State. Outbreaks have occurred in free-flying waterfowl in Maryland and Pennsylvania.

In spite of careful investigations, the source of the original U.S. outbreak has not been determined.

\section{SPREAD}

Some scientists think duck virus enteritis is usually spread by infected waterfowl that shed the virus in droppings.

The virus survives in water. It may be spread through polluted, stagnant, and slow-moving pools, ponds, and waterways. Waterfowl may pick up the disease by drinking or swimming in polluted water or eating contaminated feed. The

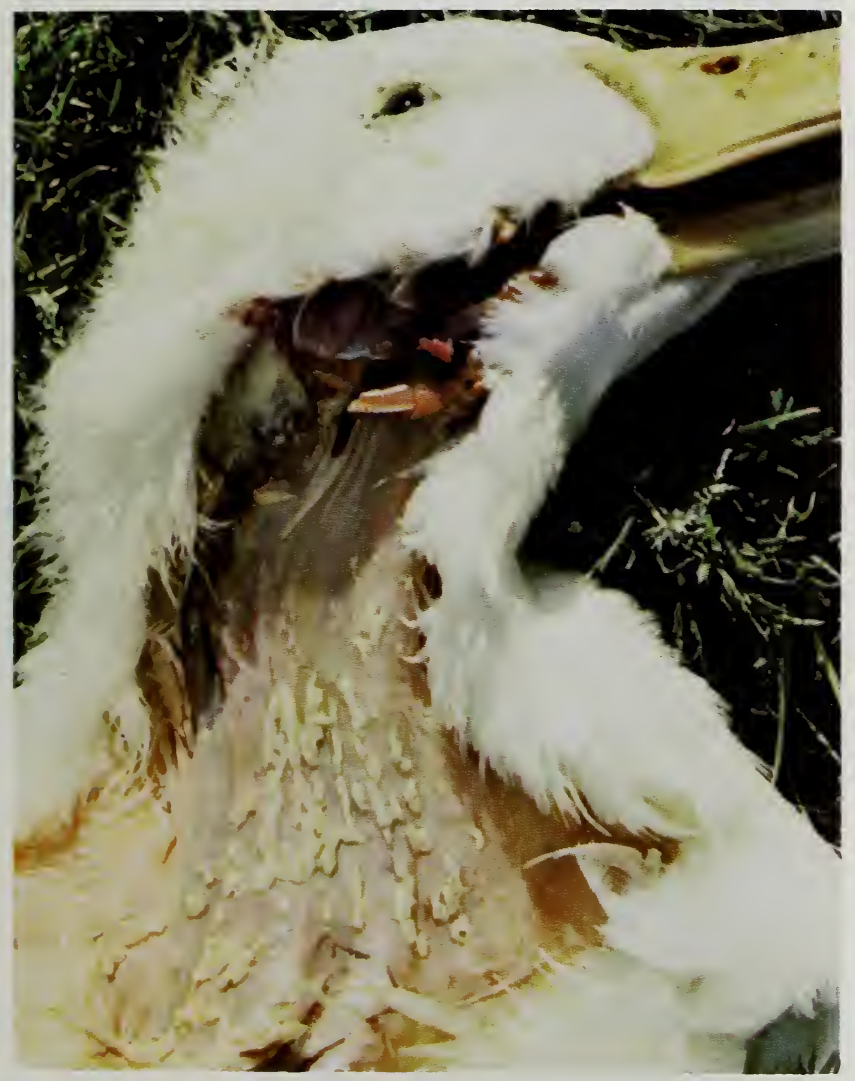

Necrotic lesions (raised grayish-white streaks) are seen in the esophagus. 


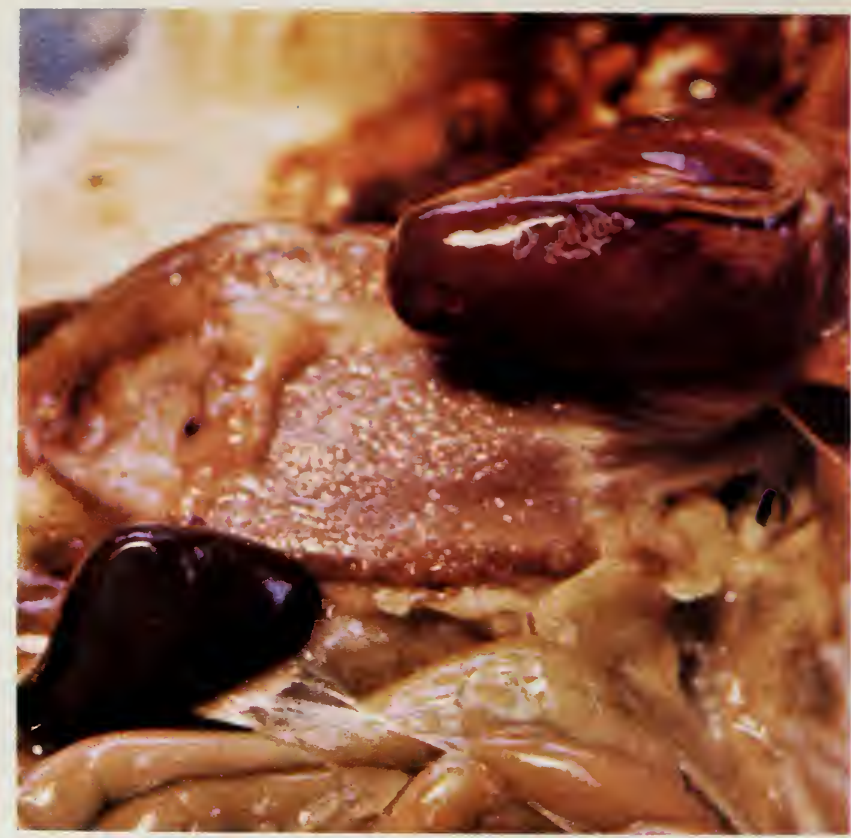

Darkened spleen (lower left) and hemorrhagic heart (upper right) are results of duck virus enteritis.

virus may enter susceptible birds through the mouth, nose, cloaca, or breaks in the skin.

The virus may possibly be spread in other ways - on equipment; through feathers, eggs, manure, and offal ; and by cats, rats, dogs, seagulls, lice, mites, mosquitoes, and man. Some people believe that migratory waterfowl may be carriers.

Duck virus enteritis may occur at any season. Many outbreaks are associated with extremes of weather. A combination of stresses - overcrowding of ducks, unsanitary pens, other diseases, and bad weather-may increase the severity of an outbreak.

The virus does not survive long in a clean, dry environment. It is readily killed by heating and disinfectants.

\section{SUSCEPTIBLE WATERFOWL}

The first outbreaks in the United States occurred in breeder flocks of Pekin ducks from 3 months to 2 years old. Since that time, the disease has appeared in breeder and market ducks of all ages - even in ducklings a few days old.

Duck virus enteritis has also been diagnosed in noncommercial Muscovy ducks and mute swans in the United States. 


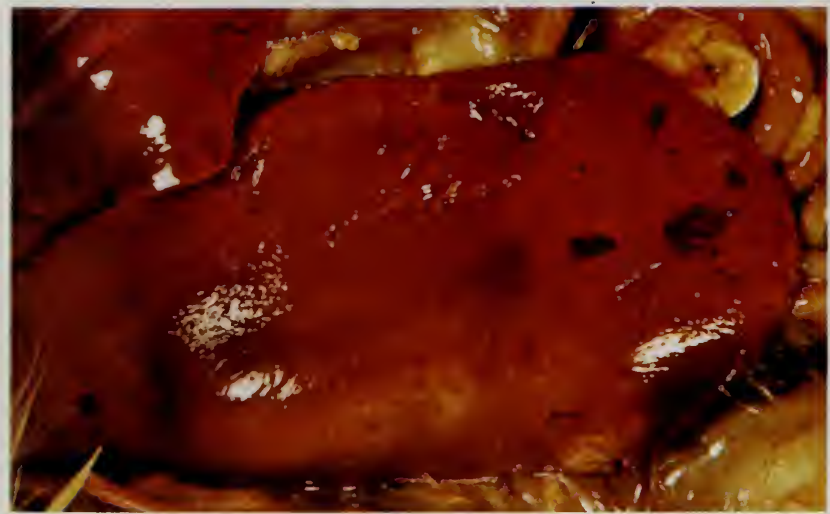

Hemorrhagic areas in the liver of a duck infected with duck virus enteritis show up as red spots.

Dutch research workers found that many ducks are susceptible - Pekin, Khaki Campbell, Indian runner, garganey teal, gadwall, widgeon, tufted, shoveler, common pochard, shell, common eider, Muscovy, and wood. Mute swans, bean geese, and whitefronted geese are also susceptible.

There are some indications that free-flying waterfowl may be carriers of the virus, even though they do not show signs of infection. Seagulls and mallards have been known to mingle with commercial ducks shortly before some outbreaks.

Duck virus enteritis is thought to affect only ducks, geese, and swans.

\section{SIGNS}

Susceptible ducks may show signs of duck virus enteritis 3 to 7 days after they are exposed. Sometimes ducks are found dead without signs of the disease having been observed.

Infected birds become listless, lose their appetites, and develop a great thirst and watery diarrhea. Occasionally, other signs are swollen eyelids and drooping wings.

Egg production drops markedly in infected breeder ducks. The eggs that are laid are usually fertile; hatchability is not affected. In birds that recover, signs of disease disappear and egg production slowly returns.

The death rate from duck virus enteritis has reached 60 percent of infected waterfowl in some flocks. In other flocks, only a few of the infected birds died. Losses are higher in flocks kept in unsanitary pens and among waterfowl affected with other diseases. 


\section{POST MORTEM LESIONS}

Post mortem lesions most often noted are spots of dead tissue in the esophagus and cloaca.

Hemorrhages usually occur in the thymus gland, esophagus, liver, and in the small intestine, including the lymphoid rings. Not infrequently hemorrhages take place in other internal organs, including the male and female reproductive tracts. The infected spleen is uniformly dark in color and may be smaller than normal.

\section{HOW TO GET A DIAGNOSIS}

If you suspect duck virus enteritis in your flock-or if you have waterfowl that die from a disease that is unknown to you-notify your veterinarian, your county agricultural agent, or a State or Federal disease-control official at once. Officials may arrange to send blood or live waterfowl showing signs of disease to a diagnostic laboratory.

\section{TREATMENT}

Successful treatment for duck virus enteritis has not yet been developed.

\section{VACCINATION}

Efforts are continuing to develop a vaccine that will protect waterfowl without spreading duck virus enteritis. Such a vaccine-when available-may be used to help control the disease.

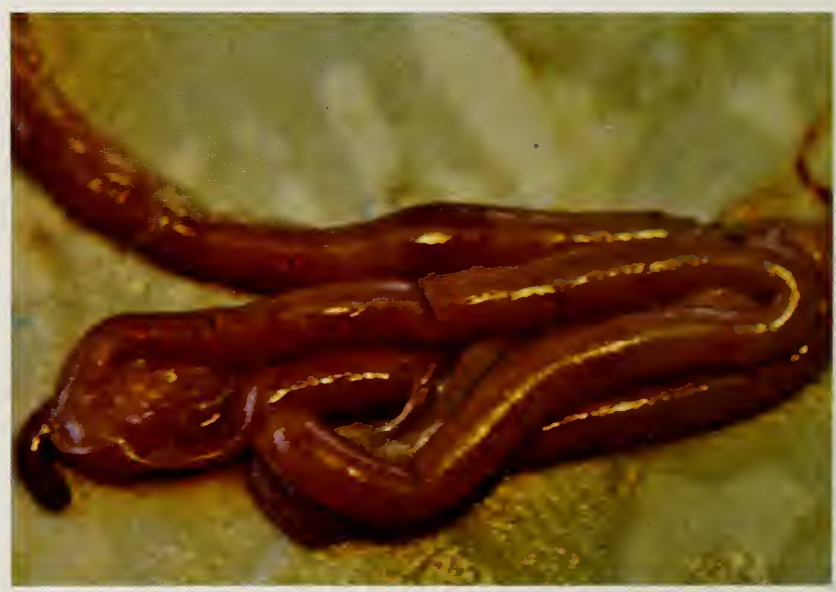

The hemorrhagic spots in the intestinal walls and the darkened, swollen band (top center) are typical of duck virus enteritis. 


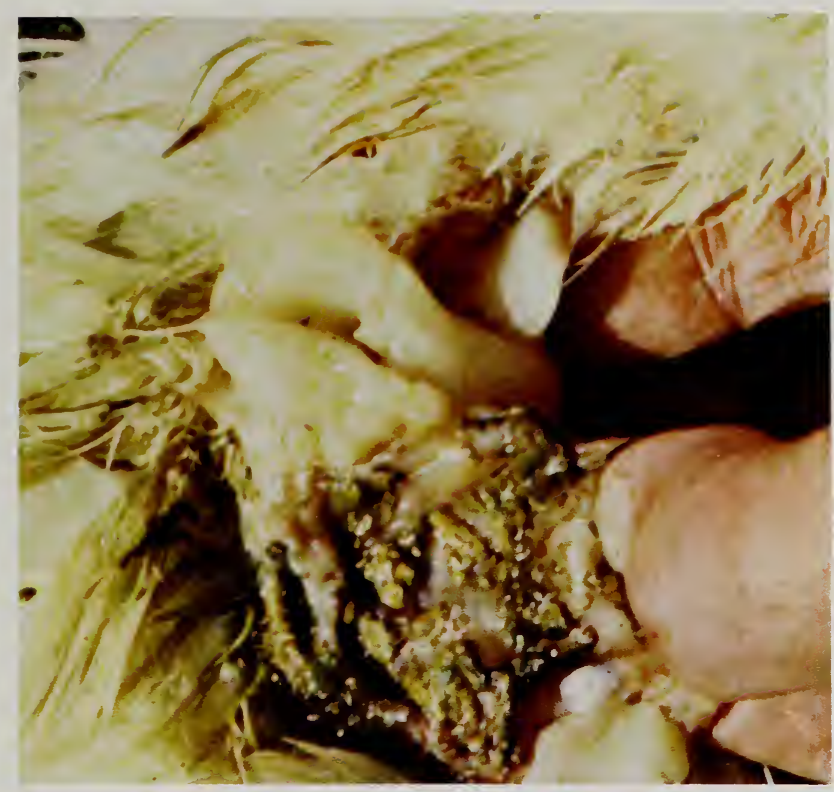

Necrotic lesions in the cloaca as shown here are unique with this disease.

\section{CONTROL}

When Pekin ducks in a commercial flock began dying from an unidentified cause in January 1967, the Long Island producer sent them to the Long Island Duck Research Laboratory. The disease was tentatively diagnosed as duck virus enteritis. The USDA's Plum Island Laboratory confirmed the diagnosis. This was the first time duck virus enteritis had been diagnosed in the United States.

Immediately, a cooperative State-Federal program was launched. University scientists joined government veterinarians in an attempt to control and eradicate the disease.

In the first outbreak all waterfowl and eggs were destroyed and buried; State and Federal indemnities were paid. Contaminated premises were thoroughly cleaned and disinfected.

Later, quarantines were established for domestic waterfowl and their products originating in Suffolk County, Long Island, N.Y. In 1969, only ducklings from approved flocks were permitted to move interstate from the quarantine area. An approved flock is one that has been inspected, tested, and found not infected. Maintenance inspections and tests are conducted in approved flocks at regular intervals to make certain the disease does not appear. 


\section{HOW THE US RWARRS AGAINST IT}

Since duck virus enteritis has been reported in the Netherlands, Belgium, India, and China, no waterfowl from these countries are permitted to enter this country.

Any other country-except Canada-that wants to import waterfowl into the United States can do so only upon the issuance of an import permit. This same regulation also applies to chickens, turkeys, pigeons, doves, pheasants, grouse, partridges, quail, guinea fowl, and peafowl of all ages. Such waterfowl and poultry are entered at the ports of New York, Miami, and Honolulu for quarantine.

\section{WhAT KOU RAD DE}

Watch for signs of disease in your flock.

Report signs of disease and unexplained deaths of domestic and wild waterfowl on your premises to your veterinarian, your county agricultural agent, or State or Federal disease-control officials.

Cooperate with State and Federal officials. Observe quarantine.

Keep your pens and premises clean. Run-off water from moats should be treated by antipollution measures.

Do not overcrowd birds.

Get your replacement birds only from flocks known to be free of duck virus enteritis.

Isolate new birds for 10 days before adding them to your flock.

Whenever possible, keep market ducks in same pen.

Clean and disinfect pens thoroughly after flock is marketed.

Collect dead ducks as soon as you find them. If carcasses are not to be sent to a laboratory, burn or bury them promptly.

If you dress or eviscerate wild waterfowl in the field, bury all offal.

Keep visitors out of any area where waterfowl are raised.

Do not visit other waterfowl farms.

This is one of a series of publications designed to acquaint American livestoch and poultry producers with foreign diseases. If you want more information, contact your local veterinarian, your county agent, or State or Federal animal disease-control officials.

Prepared by Animal Health Division, Animal Disease and Parasite Research Division, and Veterinary Biologics Division Agricultural Research Service Washington, D.C. 